\title{
Tourist Footprint and Sustainability in the Wetlands of Amazonia: A Quantification Test Based on the Area of the Regional Natural Park of French Guyana
}

\author{
Paul Rosele Chim \\ University of Antilles \\ University of French Guyana \\ University of Paris 1-Panthéon Sorbonne \\ Freddy Marcin \\ University of Antilles
}

\begin{abstract}
Wetlands are some of the most important ecosystems on Earth. We notice that the hectares of wetlands are in the grip of a certain tourist presence by means of developments whose objective is to respond to a demand for discovery, for stays more and more growing. This presence that we can qualify as "tourist footprint" questions the sustainability. The ecosystem constituted is attractive. It activates the motivations in all kinds, because being often located in the interface between the water and land areas.
\end{abstract}

The development of a territory can be achieved in a sustainable way only if a balance is found to reconcile human activity and preservation of resources. There is strong expectation in territories to enhance a territory's heritage through the growth of economic activities. This article aims to conduct a quantification test of sustainability given the growing importance of tourism in wetland type sites. We look for a relevant indicator of quantification and evaluation to examine the tourism footprint and sustainability in the wetlands of French Amazonia.

Keywords: tourist footprint, wetland-type sites, accessibility, sustainability, bioproduction, biocapacity, ecolodge, tourism development, Amazonia

\section{INTRODUCTION}

Wetlands are among the most important ecosystems on earth. Territories cannot be diversified without such a space that regenerates itself with its constituent endemic trees and plants. The ecosystem thus becomes a source of attraction with its beauty bringing pleasure to mankind. It is attractive in many ways because it is often located at the interface between water and land areas. It is argued that hectares of wetlands are grappling with providing tourist facilities to meet the demand for discovery and longer stays. This tourist activity, which is termed "tourist footprint," however, brings with it the question of sustainability. This study aims to conduct a sustainability quantifier test in the face of increasing tourism activity in wetland-type sites and develop a relevant quantifier and evaluation indicator. To achieve this 
objective, we initially discuss the accuracy of the notion of tourist footprint relating to the case under study. In the Methods section, we present the land-use area in the wetland and tourism development in the French Guiana. Followed by the results and implications, we finally list some of the developments and the limitations of the study.

\section{From Ecological Footprint to Tourist Footprint: Review of the Literature and Action Research}

In the literature on ecotourism, it is important to note that the impact and eco-systemic effect approach is not the main concern. The objective remains the development and growth of the product offer in this area. These are often niche-market operations. Hence, the notion of ecological footprint more comprehensive provides us with a better understanding of ecotourism dynamics and its effects.

The notion of ecological footprint was first used in Canada at the University of British Columbia in Vancouver in the work of Wackernagel (1994). His research focused on urban planning, which intended to highlight the impact of human presence in varied and significant forms in the use of space for productive economic purposes.

The methodology and tools used in this research remain rooted in geography and space economics. Industrial economy interferes with these two fields by considering the parameters related to distance and space. However, it changes its positioning in the treatment of the characteristic features of markets.

The process of establishing this concept gained momentum in 1996 after Rees and Wackernagel (1999)'s study, Our Ecological Footprint. In it, they argue that human action is damaging action insofar as providing ecological services is concerned. Indeed, in terms of value use, it is nature that provides services. As an intermediate consumer, production by processing raw materials challenges the circular economy.

\section{Analysis of the Area}

From the industrial economy standpoint, the notion of space cannot be disconnected from the approach of the market. In addition, from a geographical point of view one cannot ignore the physical, climatic, or topographical characteristics because as far as ecology is concerned, the hot spot is truly that of biodiversity.

At the intersection of these three disciplinary approaches, only zoning delineates a field allowing for the use of shared notions for our present study. Thus, a distinction is made between the tourist footprint and the ecological footprint. Consequently, in the analysis of space it becomes even more important to pay attention to the hotspot of biodiversity, which refers to the number of endemic species and the influx of people and activities in a zone.

Relying on geographical markers makes it possible to gain a better understanding of how space is created and structured (see Table 1).

\section{TABLE 1}

\section{GEOGRAPHICAL MARKERS}

\begin{tabular}{|c|c|c|c|c|}
\hline Markers & Scales & $\begin{array}{l}\text { Nature of the } \\
\text { footprint }\end{array}$ & Durability & Legibility \\
\hline Ostentations & $\begin{array}{l}\text { Large } \\
\text { Extended } \\
\text { Gigantic }\end{array}$ & $\begin{array}{l}\text { Deep } \\
\text { Prominent } \\
\text { Distinctive }\end{array}$ & $\begin{array}{l}\text { Long } \\
\text { Permanent } \\
\text { Help } \\
\text { sustainability of } \\
\text { space }\end{array}$ & $\begin{array}{l}\text { Noticeable } \\
\text { Explicit }\end{array}$ \\
\hline Sibylline & $\begin{array}{l}\text { Small } \\
\text { Reduced } \\
\text { Occasional }\end{array}$ & $\begin{array}{l}\text { Light } \\
\text { Superficial } \\
\text { Discreet }\end{array}$ & $\begin{array}{l}\text { Short } \\
\text { Ephemeral } \\
\text { Temporary }\end{array}$ & $\begin{array}{l}\text { Identifiable } \\
\text { Implicit }\end{array}$ \\
\hline
\end{tabular}

Elaborated by Paul ROSELE CHIM, 2020 
Ostentatious markers are of consistent size. They create and structure space. Indeed, they are permanently inscribed. For instance, in French Amazonia, when one arrives in Incas Wayana, Wayampi, Saramacas, Bushinengué, and Aloukou lands, places appear like the externalities of another entirely different system, like another world in the Cosmos.

These markers are situated at the periphery of central places that punctuate the daily life of urban and industrial societies. The difference between these central places and the space beyond the markers contributes to highlighting the feeling of otherness tourists expect from such places.

Sibylline markers are small, and they emphasize the singularity of space since they are discreet. We notice striking differences within a linear and vast ensemble, without triggering any particular attractiveness, but with a light footprint that discreetly calls it into question by introducing a second level that becomes a specificity inside the place. As such, in a large place, the sibylline marker highlights the characteristics of differentiation, comparison, competition, and performance when it comes to developing ecological services. The tourist function of these places is boosted because there is a co-spatiality between the visitors and the permanent residents of these places.

\section{Wetland Footprint Approach}

To our knowledge, the literature does not deal with the tourist footprint in wetlands. Our field research would help in gaining a better understanding of this issue. We make the following observations from the wetland shelter experience.

The first type of shelter is that built by hunters and fishermen. These are huts built in wooded areas and they allow for the surveillance of game. Farmer peasants also build wooden houses to keep track of herds, or merely for accommodation during periods of agricultural labor. Accessibility is limited to these shelters. These footprints are extensive in space. The effects are weak.

The second type of shelter is linked to intensive but local and limited economic activities. This type of shelters is characterized by sedentary practices, a permanent presence allowing for interactions and exchanges, comings and goings, and water transportation between territories whose difference in population density is reflected in their rural and urban characteristics. Accessibility is at the heart of the dynamic development of these spaces. Footprints are intensive. The effects are strong.

The third category is observed in areas marked by the confluence of water and land. These shelters demand significant investments according to the intended purpose, because of the risks involved, which are twofold: accessibility and sustainability. The risk of accessibility involves a level of material organization allowing for setting up of the shelter. The risk of sustainability is reinforced by developing activities for the shelter to become a place of accommodation. When these risks are mastered by the actors, footprints grow. The effects are strong.

\section{Lodges}

It is noted that huts, wooden houses, and ajoupas are the shelters that constitute the first type of accommodation in the wetlands and forests. The habitat becomes one with the surrounding forest: the roof is made of leaves, generally from palm trees, the wooden frame is connected with lianas and natural fibers. The concept of lyannaj comes from this technique. These facilities are located alongside rivers, creeks, beaches, in the middle of a wet savanna, and inside natural or national parks. They are fully integrated into the population's life. The quality of the environment highlights the distinctive character of the accommodation. Comfort and hygiene grapple with isolation, service, and accessibility. In Amazonia, this type of accommodation offering discovery activities is a stopover for tourists in the forest. One may reach this type of accommodation, which is often secluded or in a virgin environment, only by navigating on rivers, which is why the presence of guides and boatmen is necessary. Activities are nature oriented, for instance, walks in the forest, canoeing, observing flora and wildlife, learning about entomology, traditional netting, trapping or traditional fishing, discovering traditional villages, having ethnic encounters, learning archery, and getting an initiation to life in the forest and aboriginal activities such as crafts and gold panning. 
The ecolodge approach aims at building substantial tourism that fits into the wet natural environment by offering a variety of activities based on the natural ecosystem. The main aspect here is the endogenous social fabric and the human presence. A lodge in the wetland is a type of accommodation built on an aquatic space such as a pond, lake, lagoon, or swamp. It may be adjacent to aquatic environments housing fish, birds, and wildflowers. Lodges are made of wood, equipped with beds, dishes, bathroom, kitchen, and other facilities. They offer a breathtaking view of the natural surroundings. However, they call into question the preservation of the environment, putting at stake the balance between tourist activity and ecology.

\section{Sustainability}

In French Amazonia, specificities are often noted: remarkable sites, atmosphere of serenity, fundamental know-how legacy, and requirements of sustainability. The remarkable sites are ostentatious markers that structure the territory in the North and South of the Amazon River. Populations are distributed on both sides of these remarkable sites, which delimit countries in terms of places with an atmosphere of serenity ingrained in its very ancient cultures and civilizations (e.g., Inca world, Mayan world, Wayana, Wayaki, Saramaca, Bushinengue peoples, etc.).

Knowledge intensifies the research motivation of industrial, cosmetics, and pharmaceutical firms for extracting natural resources (oil, gas, minerals, molecules for medicine, etc.). The use and non-use of the services provided by nature in Amazonia have led to struggles with the effects of irreversibility, and hence, the need for quantification and evaluation of footprints. Accessibility reflects the strong hypothesis of human presence. Wetlands made accessible question the effects of the growing human presence and activities in remote sites. Undoubtedly, when it comes to accommodating people, the norms in use must be respected. The quality process is essential for sustainable tourism.

On the demand side, when expectations and the guarantee of the quality of services are considered, determinisms are activated. On the supply side, the professional is grappling with the best stable product and an image that certifies it through the channels of communication. Quality and qualification are the basis of the strengths and weaknesses of the market. The supplier can thus consider necessary the efforts and the follow-up to achieve a certain level of performance.

\section{METHODS}

We focus on a multi-varied cross-analysis. It implies a shift in our disciplinary positioning by going back and forth between several approaches: social sciences, management sciences, or quantitative techniques. The use of ecological sciences strengthens our investigations for the statistical study, the economic calculation of quota, and the creation of models. This analysis is based on the Global Footprint Network (GFN). The footprint is measured mainly on the surface, in hectares per individual to match some needs. The notion of biocapacity per person helps us measure the ecological services provided by nature. Bioproductive quantification to meet the need an individual or a population provides a concrete idea of the impacted area. Hence, the demand for natural resources is linked to supply; in other words, the capacity of ecosystems to provide these resources within the limit of their regenerative force is what the notion of biocapacity encompasses. It may be recalled that since 1985, the ecological footprint has exceeded the overall biocapacity of the planet. We reckon that the regenerative capacity of the Earth can no longer keep pace with the demand, that is, resources are turned into waste faster than nature can turn these wastes into resources.

Nevertheless, this does not mean that all countries and all territories are impacted in the same way and to the same level. With this approach, our aim is to educate citizens on their way of life and to measure the effects of a policy of sustainable development led by those in power. The indicator used is the gha or hag (global hectares) that can be converted to $\mathrm{gm}^{2}$ (global square meters). This may be supplemented by local factors (noise, clutter, etc.).

By examining the projected data of the World Tourism Organization (UNWTO), we are left wondering about the so-called biodiversity hotspots. According to Conservation International, this 
corresponds to areas hosting at least 1,500 species of endemic plants and having lost at least $70 \%$ of their original inhabitants. We also consider a significant number of aquatic, flying, or terrestrial species. The case study that we develop on French Guiana can help us find a solution to the a possible mitigation of the footprint in terms of regional tourist flows during the present period.

TABLE 2

EVOLUTION OF GLOBAL TOURIST FLOWS

\begin{tabular}{lllll}
\hline Years & $\begin{array}{l}\text { Arrivals in } \\
\text { millions }\end{array}$ & Growth & $\begin{array}{l}\text { Revenue in } \\
\text { billions of dollars }\end{array}$ & $\begin{array}{l}\text { Growth in real } \\
\text { value }\end{array}$ \\
\hline $2009-2010$ & 880 & $4 \%$ & 852 & $6 \%$ \\
$2010-2020$ & 1600 & $45 \%$ & 2000 & $54,4 \%$ \\
\hline
\end{tabular}

WTO 2018

TABLE 3

EVOLUTION OF TOURIST FLOWS IN FRENCH GUIANA

\begin{tabular}{|c|c|c|c|c|}
\hline Years & $\begin{array}{l}\text { Arrivals in } \\
\text { millions }\end{array}$ & Growth & $\begin{array}{l}\text { Revenue in } \\
\text { billions of dollars }\end{array}$ & $\begin{array}{l}\text { Growth in real } \\
\text { value }\end{array}$ \\
\hline 2005-2009 & $\begin{array}{l}37500 \text { of which } \\
11500 \text { space } \\
\text { industry }\end{array}$ & $-11 \%$ & $\begin{array}{l}81 \text { million euros } \\
\text { (without airline } \\
\text { Tickets) }\end{array}$ & \\
\hline 2009-2010 & 83000 & $5 \%$ & $\begin{array}{l}150 \text { million euros } \\
\text { (with airline } \\
\text { tickets) }\end{array}$ & $15 \%$ \\
\hline 2010-2020 & 200000 visitors & $40 \%$ & $\begin{array}{l}300 \text { million euros } \\
\text { (forecast) }\end{array}$ & $50 \%$ (forecast) \\
\hline
\end{tabular}

Elaborated by Paul ROSELE CHIM 2020 as from IEDOM datas 2019

\section{WETLAND AND LAND USE OF THE AREA}

In relation to the elements discussed in the aforementioned literature and methodology, it is important to examine the wetland and the land use of the area. In French Guiana, the climate is equatorial and intertropical humid. The effect of the Earth's rotation on this territory is shown in two periods. First, the dry and short period and then the wet and long season. Daily temperature varies slightly throughout the year. Solar radiation is constant. The Winds from the Atlantic Ocean keep the temperatures balanced (Météo-France, climat Guyane, 2011). Hence, the alternation between the dry and wet seasons occurs following the passage of the intertropical convergence zone (ZIC), which meteorologists explain by the strength in the number of convective cells that generate heavy rainfall (SDAGE, 2016-2021). 


\section{FIGURE 1}

AVERAGE MONTHLY TEMPERATURES IN FRENCH GUYANA IN 2016

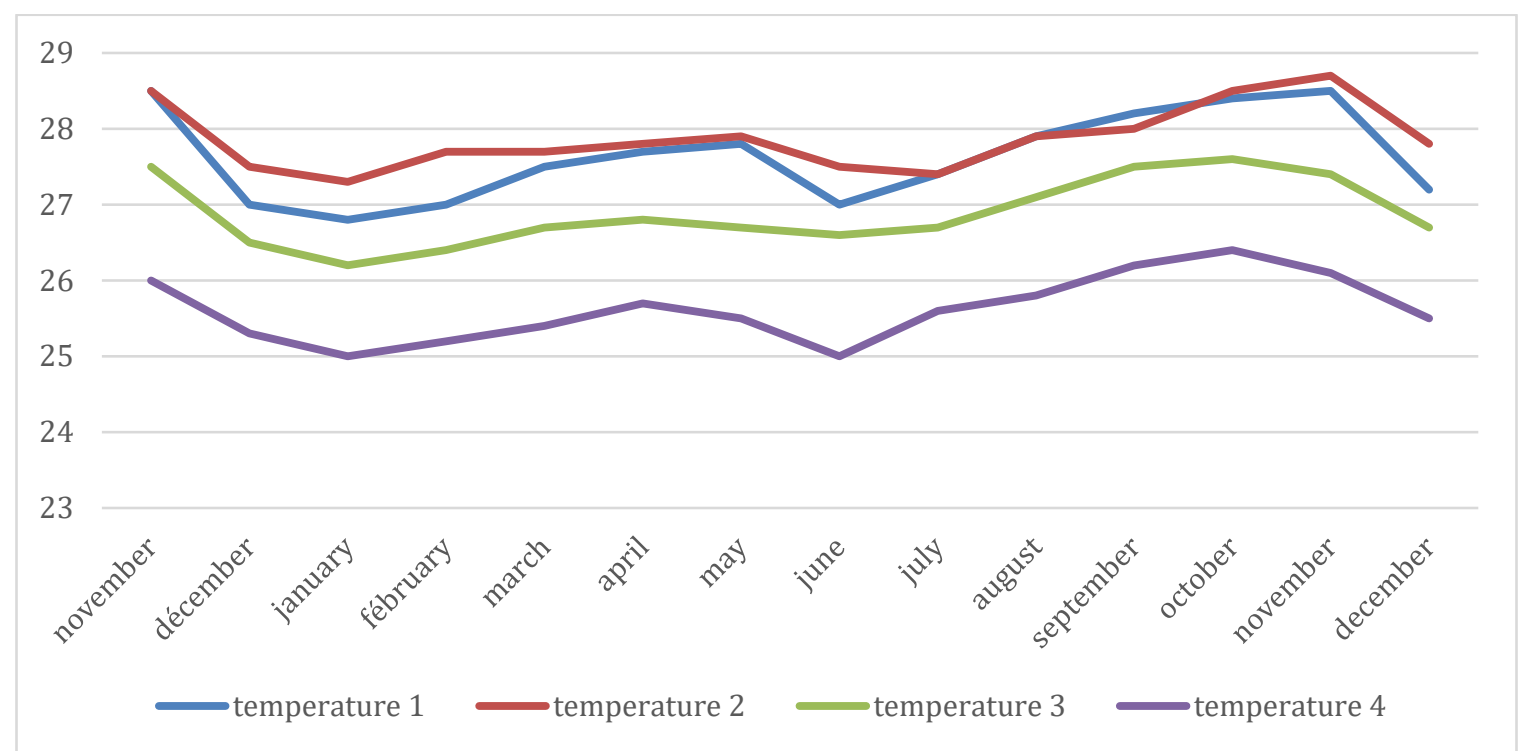

Elaborated by Paul ROSELE CHIM 2020 as from Météo France Datas

FIGURE 2

ANNUAL RAINFALL IN FRENCH GUYANA SINCE 1961

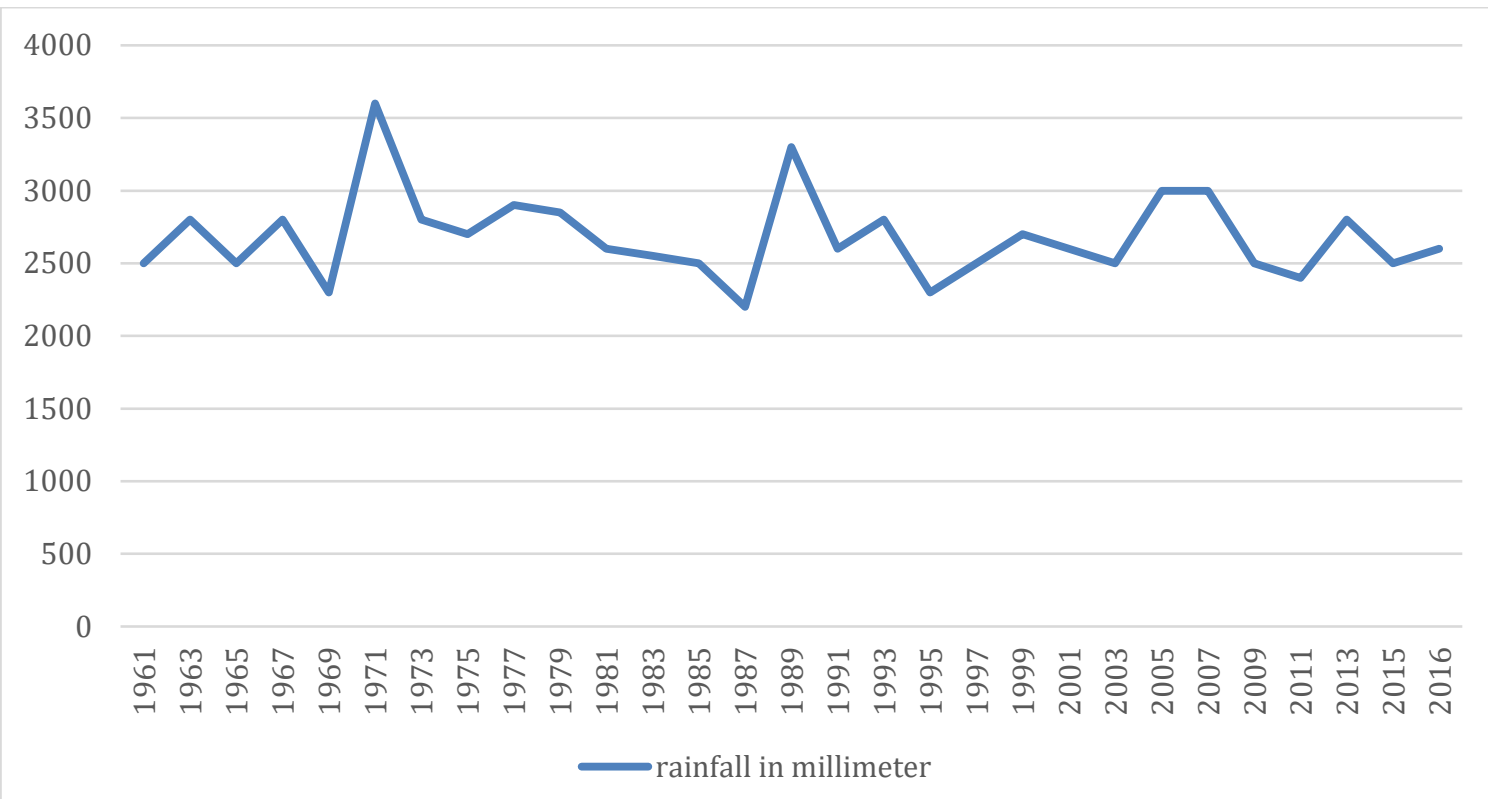

Elaborated by Paul ROSELE CHIM 2020 as from Météo France datas

Figures 1 and 2 show the temperature level to be around $27^{\circ} \mathrm{C}$ and the average annual moisture content to be around $85 \%$. The climate is characterized by very high annual rainfall of about $3000 \mathrm{~mm} /$ year and alternates between a short dry season and a long rainy one. Annual rainfall ranges from 2000 $\mathrm{mm}$ to $4000 \mathrm{~mm}$. Rainfall is very heavy in the areas called Kaw-Roura-Cacao. It is less significant in the south, the southwest, and the far west. Kaw territories bear maximum rainfall because they comprise 
mountains that mark the first high shapes of relief from the ocean. On rising, the clouds and winds, which are filled with humidity, pour out. This explains why rainfall is up to $4000 \mathrm{~mm} /$ year, while in the Awala Yalimapo areas, rainfall, though abundant, is relatively lower, generally around $1800 \mathrm{~mm} /$ year.

\section{FIGURE 3 \\ RAINFALL IN FRENCH GUIANA IN 2016}

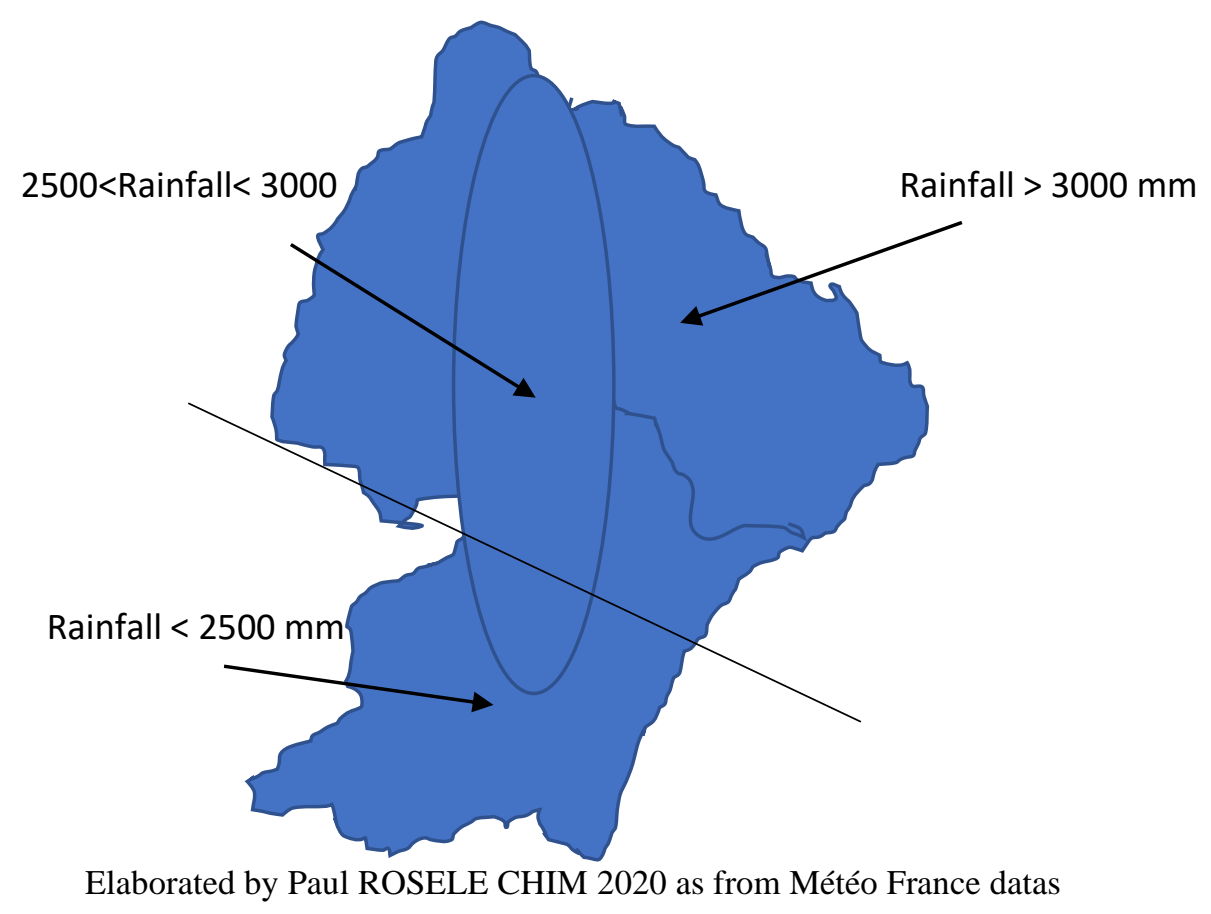

Figure 3 shows some differences in the distribution of rainfall in the area under study. Darker colors correspond to very heavy rainfall compared to the inside areas where rainfall remains significant but weaker. Given such a state of affairs, how can land be utilized in this area?

Based on field research, we notice varied sites on the PNRG territory which presents an abundant biodiversity belonging to the same category, in other words, the wet and dry zones. These habitats demonstrate diversity from the East to the West by harboring species in range lites of division. At the interface between sea and earth, a gradient of environments and a diversity is seen from the north to the south. 


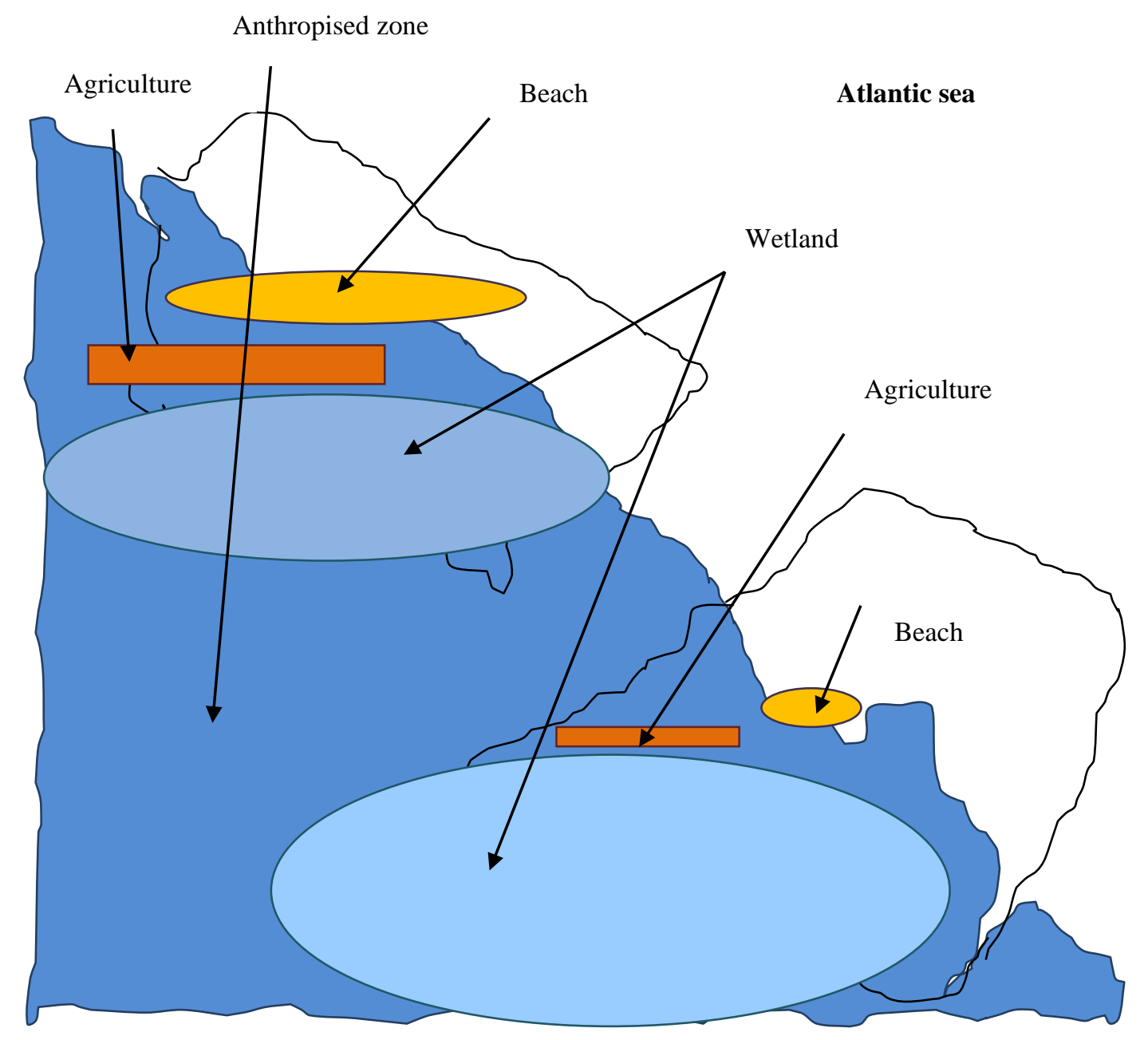

Elaborated by Paul ROSELE CHIM 2020

The chosen indicator is expressed in ha. It is necessary to synthesize its representativeness with respect to the partitions of the area. Table 4 shows with clear precision this representativeness of the environments. It is observed that the urban environment represents only a small percentage.

\section{TABLE 4}

\section{REPRESENTATIVES OF THE HABITATS}

\begin{tabular}{lcc}
\hline Land Use & Surface in ha & Representativeness inside the PNR \\
\hline Wetlands & 281736 & $32 \%$ \\
Swamp & 55148 & 65 \\
Forest & 528074 & $59 \%$ \\
\hline
\end{tabular}




\begin{tabular}{lcc}
\hline $\begin{array}{l}\text { Agriculture Livestock, } \\
\text { pasture }\end{array}$ & 17197 & $2 \%$ \\
$\begin{array}{l}\text { Open areas Dry and rocky } \\
\text { savannas }\end{array}$ & 647 & $0,07 \%$ \\
$\begin{array}{l}\text { Beach } \\
\text { Urban area, antropised }\end{array}$ & 26 & $0,003 \%$ \\
Total & 9098 & $1 \%$ \\
\hline
\end{tabular}

Elaborated by Paul ROSELE CHIM as from PNRG datas on French Guyana 2019

\section{FIGURE 5 \\ LAND USE DIAGRAM BY TYPE OF ENVIRONMENT}

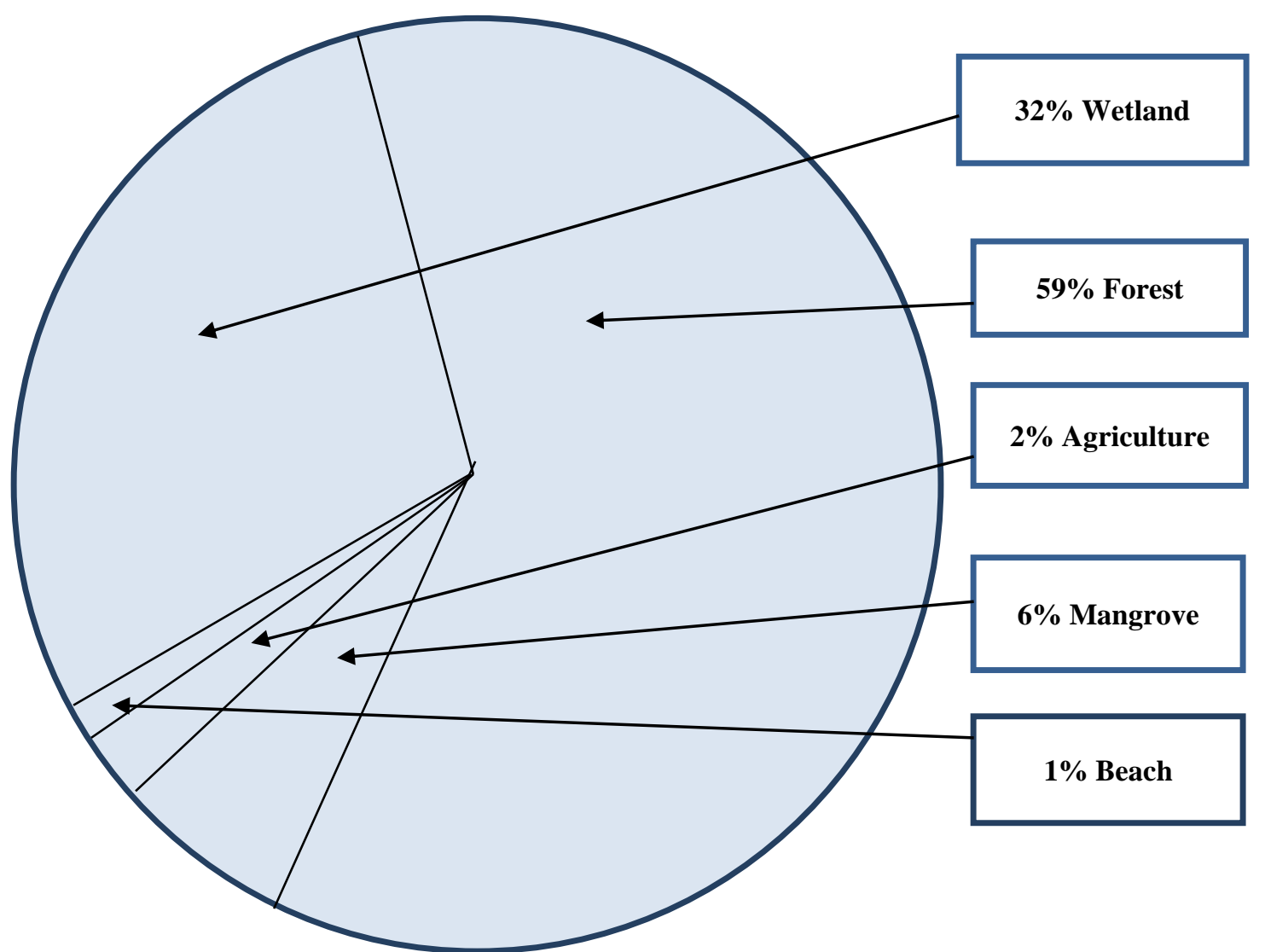

Elaborated by Paul ROSELE CHIM as from PNRG datas on French Guyana 2019

The studied surface is $65 \%$ covered by forest and swamp. Wetlands cover $32 \%$. Urban areas and agriculture barely reach $2 \%$, including open areas such as beaches, dry savannahs, and rocky ones. This environment does not correspond to a classified typology of territory. Only a functional approach and the dynamics of the remarkable sites make it possible to clarify the study of footprint and sustainability by quantification and evaluation.

\section{OVERVIEW OF TOURISM DEVELOPMENT}

In 2009 , the tourist flow was 83,000 visitors; $87 \%$ of them came for business purposes or by affinity. Arrivals were 110,000. Leisure tourism reached $17 \%$ in 2015 with the volume of arrivals reaching 220,000 (CTG, 2015). 
FIGURE 6

TOURISM PRACTICE IN FRENCH GUYANA

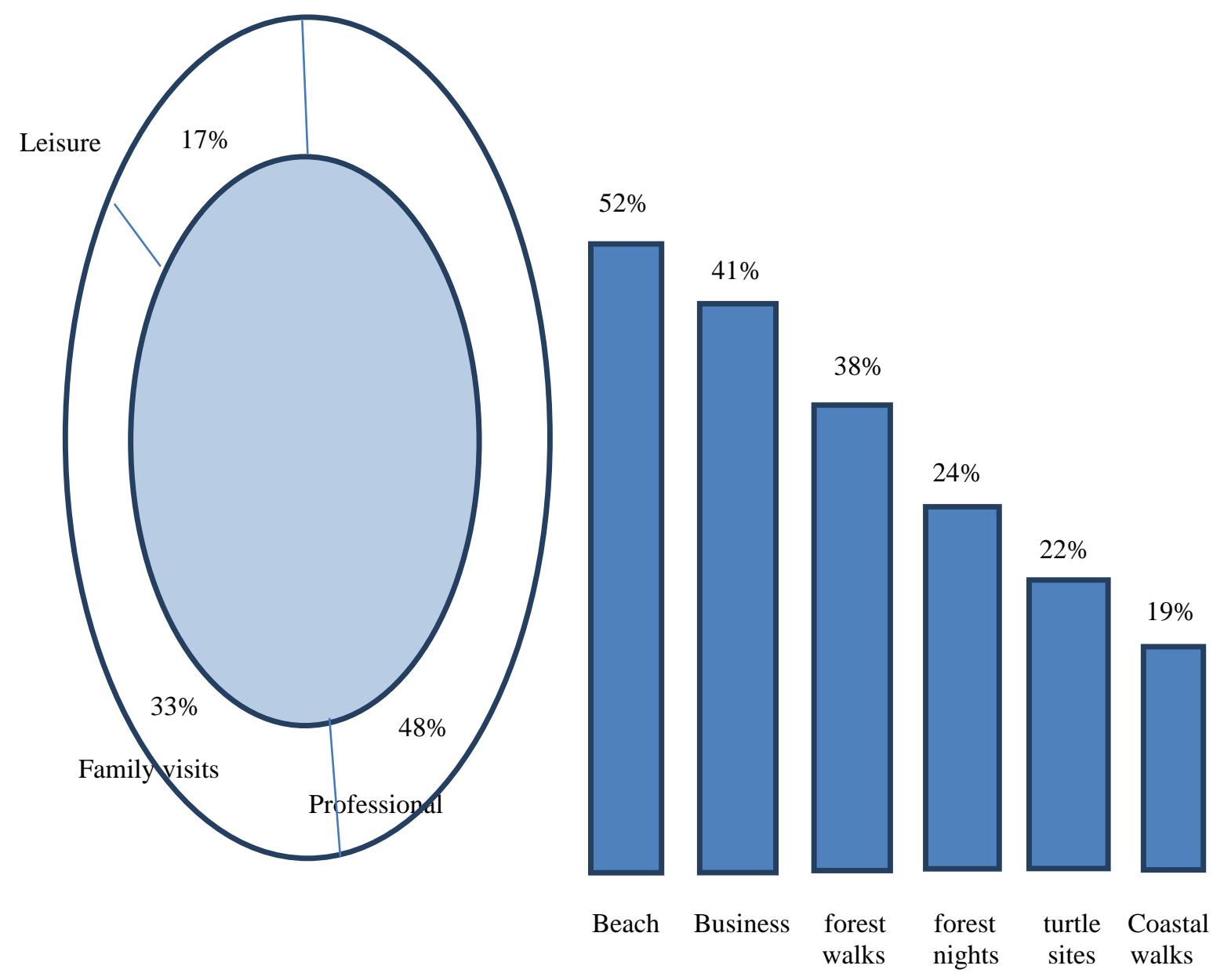

Elaborated by Paul ROSELE CHIM as from datas of Regional tourism committee of French Guyana 2019

Surveys reveal that visitors enjoy the beaches of Guiana although the water is not crystalline. The bodies of water are vast. This allows great comfort with typical scenic areas, and a progressive dive thanks to the gentle slopes at the water's edge. In 2013, the occupancy rate was 30\%, in 2015 it was $50 \%$ with 354,140 nights in hotels that represent $60 \%$ of the total accommodation capacity in French Guiana.

TABLE 5 2016 KEY FIGURES FOR TOURISM IN GUIANA

\begin{tabular}{|l|l|l|l|}
\hline Accommodation & Hotels & $\begin{array}{l}\text { Furnished rooms and } \\
\text { guesthouses }\end{array}$ & $\begin{array}{l}\text { Tourist camps and } \\
\text { guestfarms }\end{array}$ \\
\hline Number & 39 & 267 & 60 \\
\hline $\begin{array}{l}\text { Accommodation } \\
\text { capacity }\end{array}$ & 3812 & 859 & 1645 \\
\hline $\begin{array}{l}\text { \% of total } \\
\text { accommodation }\end{array}$ & $60,5 \%$ & $11,5 \%$ & $26 \%$ \\
\hline
\end{tabular}

Elaborated by Paul ROSELE CHIM as from French Guyana Tourism Committee datas 2016 


\section{FIGURE 7 \\ DISTRIBUTION OF THE ACCOMMODATION ON THE PNRG TERRITORY}

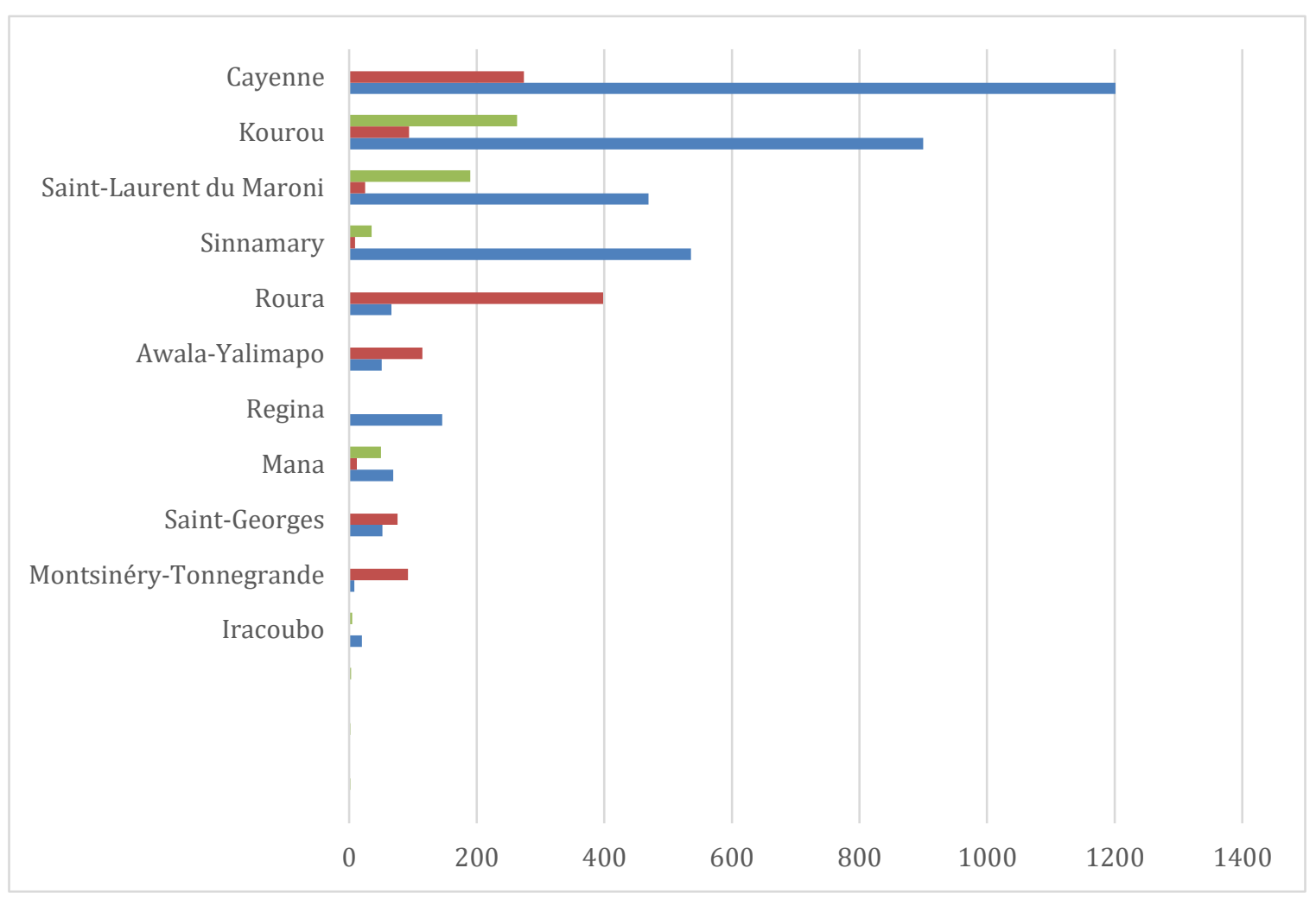

SIMA-PECAT as from SRDTL Datas 2018

Accommodation is uneven and intended for business tourism. Among the 39 hotels, 53\% of which are classified are mainly located in the areas of Saint-Laurent du Maroni, Kourou, Sinnamary, and Cayenne. Their activity is linked to that of the space industry. Furnished rooms, guest houses, and lodgings represent 267 accommodation options, of which 28 are registered. In 2016, there were 60 tourist camps and guest farms that formed bivouac areas set up in natural surroundings. The facilities include sleeping arrangements and use of common equipment. Drinking water is not necessarily available. The guest farm offers a bed in a hammock. The habitat is traditional and integrated into the natural environment. The owners comply with the regulations enacted by the charters. Nevertheless, development of accommodation in the forest in relation to the environment of the Amazon offers a unique experience. These types of accommodation are called "ecolodges" in the wetlands.

The West Pole offers potential ecotourism in development, which aims at authenticity, enhancement of the archaeological, cultural and natural heritage, and the know-how of the indigenous populations. 
FIGURE 8

MAIN TOURIST ACTIVITIES OF THE WEST POLE

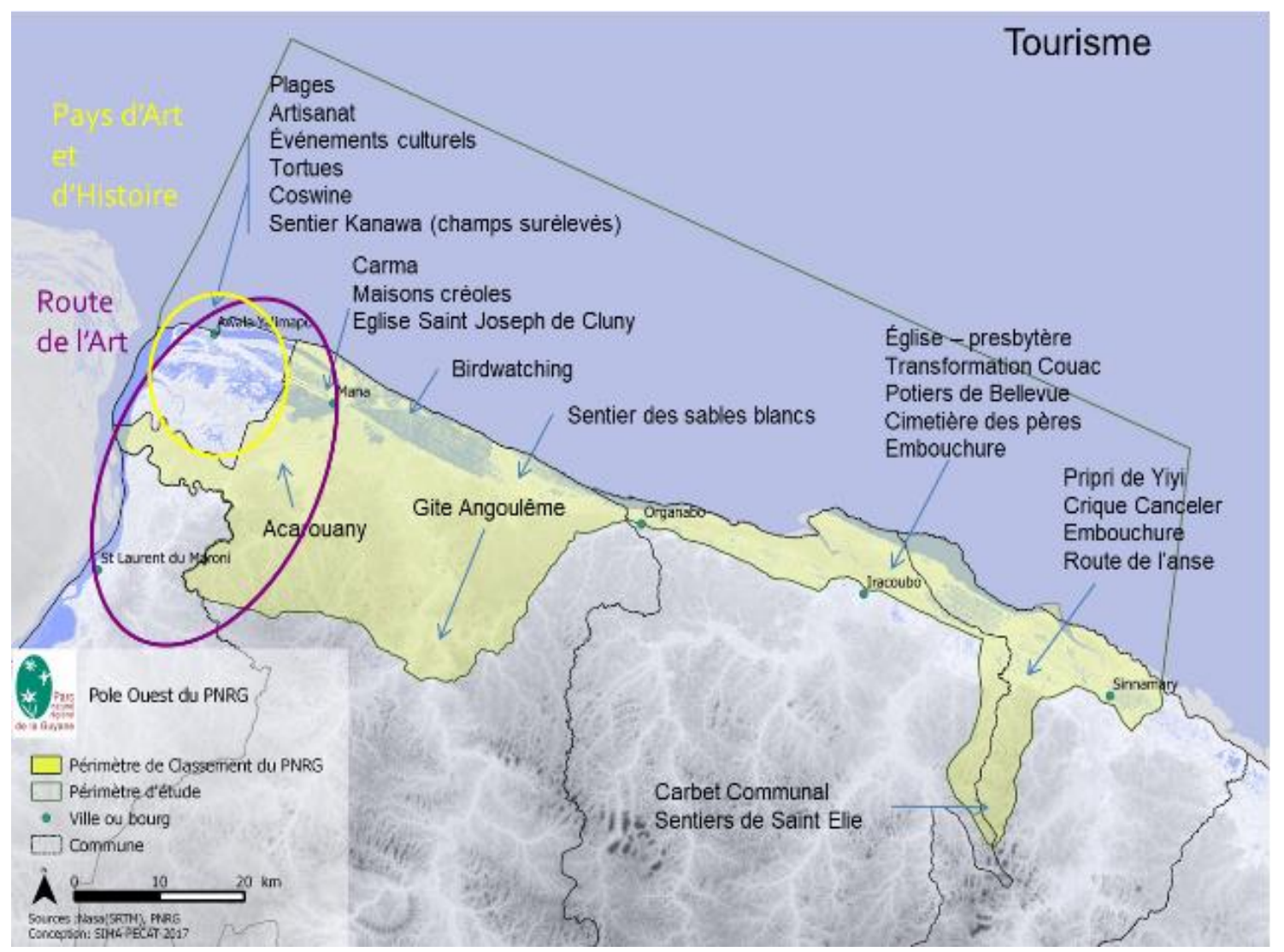

PNRG 2019

The East Pole offers a tourism network that shows unequal distribution and is declining. It covers cottages that highlight the authentic character, mainly the carbet. The Kaw-Roura Nature Reserve is the fourth most visited site to which the locality of Cacao may be added. 
FIGURE 9

MAIN TOURIST ACTIVITIES OF THE EAST POLE (NON-EXHAUSTIVE LIST)

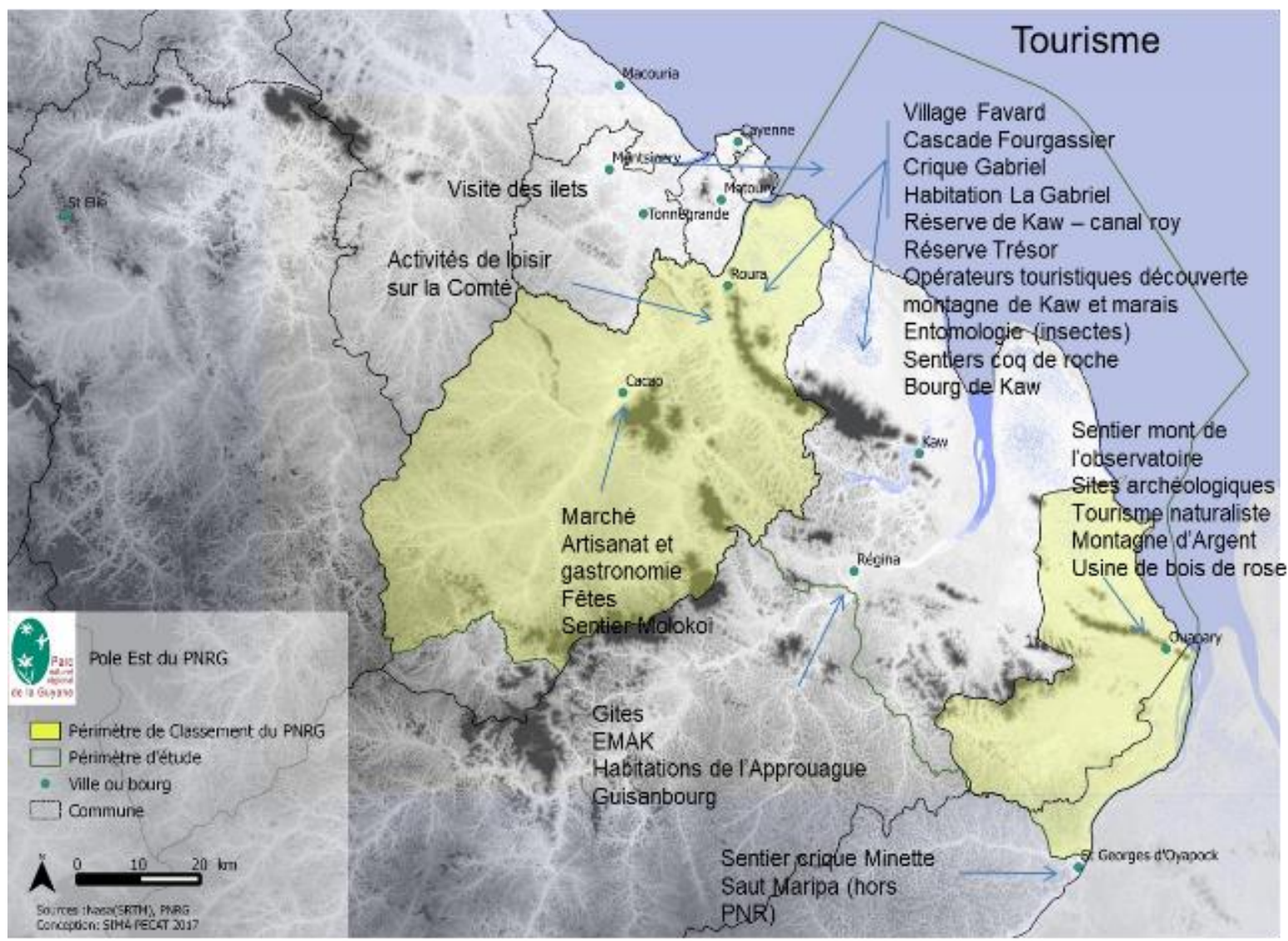

PNRG 2019

The secluded nature of certain territories, especially that of Kaw and Ouanary, is an advantage to enhance the authentic setting offered to visitors. In Kaw, tourist accommodation was developed in humid zones, on floating carbets or on dry land. The naturalistic and archaeological tourist potential is exploited and attempts are made to enhance this on the islands. 


\section{LOCATION OF ENVIRONMENTAL AND CULTURAL EDUCATION SITES, AND TYPOLOGY OF ACCOMMODATION BY MUNICIPALITY}

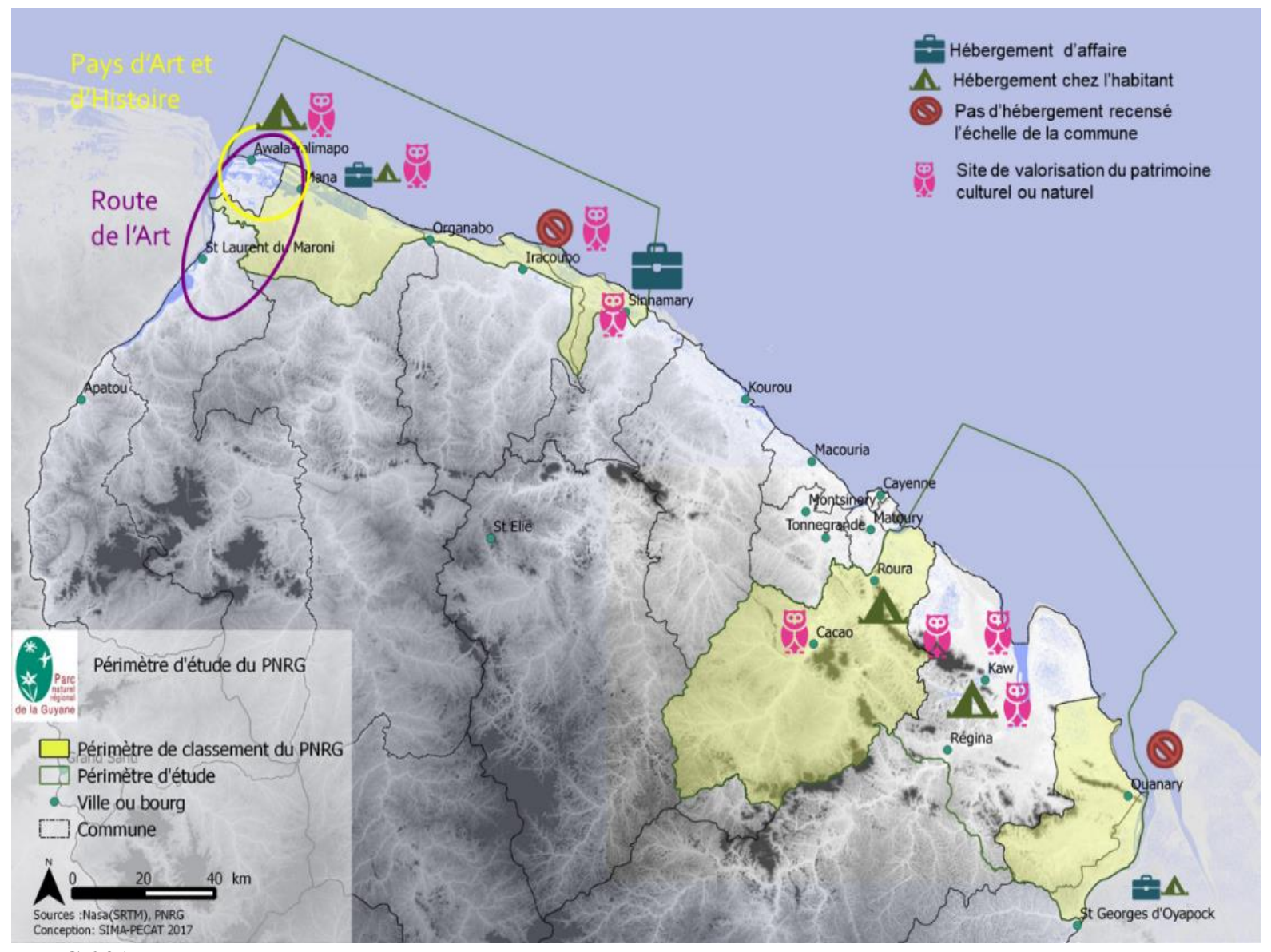

PNRG 2019

\section{CASE STUDY OF THE WETLAND TOURIST FOOTPRINT}

In this study of the tourist footprint in French Guiana, one can observe consumption of local products and a range of solutions for transportation and conservation. Most of the tourist footprints can be seen in energy consumption, namely lighting, air conditioning, and use of household appliances. With increasing travel by car or by air, the footprint is growing and one of the residual effects of this is observed in the increase in waste production.

\section{Forecast and Calculation} 2030 ?

Based on the hypothesis that this trend undergoes no change, what could be the Guianese footprint in

The following parameters are used to calculate this:
Gs: Guianese surface
Fs: forest surface
Ps: Pasture surface
Es: energy surface
Cls: cultivated land surface
Ms: Maritime surface Us: Urban surface
$\mathrm{W}=[(\mathrm{Gs}+\mathrm{Fs}+\mathrm{Ps}+\mathrm{Cls}+\mathrm{Ms}+\mathrm{Us}+\mathrm{Es}) / \mathrm{Pop}]$
$\mathrm{W}=\mathrm{E}$ 
Thus, the footprint is measurable in a gross way. It can be considered that each Guianese is entitled to E hectares per year for food, clothing, drink, housing, and removing and absorbing emissions that arise from their energy consumption. For them to live in a sustainable way, the average ecological footprint of each person should not exceed the available bioproductive surface. It should be below E. From the GFN data, it must be remembered that to produce 1 kilo of meat, it takes $10 \mathrm{~m}^{2}$ of pasture, $11 \mathrm{~m}^{2}$ of cultivated surface, $2.4 \mathrm{~m}^{2}$ of built surfaces, and $21 \mathrm{~m}^{2}$ of energy surface to absorb the $\mathrm{CO}_{2}$. The total ecological footprint of a country is dependent on the size of the population. The world average is 2.7 hag. Differences exist between countries. Table 6 gives a comparative account of the area footprint on the planet. We consider that the data related to Belgium indicate distortions that may appear within an area.

\section{TABLE 6 \\ AREA ECOLOGICAL FOOTPRINT}

\begin{tabular}{ll}
\hline Areas / Countries or territories & hag \\
\hline USA & 9,2 \\
Africa & 1,4 \\
Non European Union & 8,5 \\
European Union & 4,98 \\
Middle East + Central Asia & 2,84 \\
Asia - Pacific & 1,80 \\
Belgium & 5,1 \\
\hline
\end{tabular}

Report alive Planet 2008, GFN and ZSL Lining Conservation

We must pay attention to the fact that the footprint may vary within a country depending on the lifestyle and the area. If the footprint is high, there is an ecological debt, that is, the natural resources are used so quickly that they cannot regenerate, to the point where there is an obligation to tap into the environment stocks until disappearance. Hence, the necessity arises to consider importing resources. Debt is also reflected in increasing the production of waste. The balance model in this field is related to countries in Africa, the Middle East, Central Asia, and the Asia Pacific. In table 6, the footprint for these countries is low. That of an inhabitant is close to the biocapacity of the terrestrial territories. French Guiana is a large but sparsely populated country.

$$
\begin{aligned}
& \text { EPNRG }=[\text { WPNRG } / \text { POPPNRG }] \\
& \text { EPNRG }=[891926] /[22475] \\
& \text { EPNRG }=39,68
\end{aligned}
$$

In the whole country, EGUY = [ WGUY] / [POPGUY]

$\mathrm{EGUY}=[$ 8353400]/[295668]

$\mathrm{EGUY}=28,25$

These results can be interpreted bearing in mind that the available space is, as per the PNRG, 39.68 global ha per person. It is 28.25 when applying this calculation to the entire Guianese territory. It can be argued that Guiana has an ecological surplus in all the cases examined, because, by retaining the indicator of the GFN, one arrives at the following bioproduction:

(1) $\mathrm{EPNRG}=39,68$

$39,68 \times 10000=396800 \mathrm{~m}^{2}$

To produce 1 kilo of meat, it takes $44.4 \mathrm{~m}^{2}$

(3) $[396800] /[44,4]=8936,93$ kilos

(4) Bioproduction $=8,93693$ tons

If we keep EGUY $=28,25$, the following is the result:

(1) $\mathrm{EGUY}=28,2528,25 \times 10000=286800 \mathrm{~m}^{2}$

(2) To produce 1 kilo of meat, it takes $44.4 \mathrm{~m}^{2}$

(3) $[286800] /[44,4]=6459,45$ kilos

(4) Bioproduction $=6,45945$ tons 
By applying our method and calculating over a very long period of 68 years, from 1951 to 2019, we obtain the following footprints and bioproduction (Table 7):

FIGURE 7

FOOTPRINTS AND BIOPRODUCTION

\begin{tabular}{|c|c|c|c|c|c|c|c|c|c|}
\hline Years & 1951 & 1955 & 1959 & 1963 & 1966 & 1967 & 1968 & 1969 & 1970 \\
\hline $\mathrm{E}$ & 322,986 & 295,78 & 272,10 & 238,17 & 219,30 & 210,10 & 201,14 & 192,58 & 184,67 \\
\hline Bioproduction & 72,744 & 66,617 & 61,238 & 53,641 & 47,319 & 45,301 & 43,373 & 41,592 & 39,990 \\
\hline Years & 1971 & 1972 & 1973 & 1975 & 1979 & 1983 & 1987 & 1990 & 1995 \\
\hline $\mathrm{E}$ & 171,25 & 165,59 & 160,40 & 150,86 & 132,37 & 110,89 & 87,96 & 73,90 & 61,74 \\
\hline Bioproduction & 58,569 & 37,295 & 36,128 & 33,977 & 29,813 & 24,975 & 19,810 & 16,644 & 13,905 \\
\hline Years & 2000 & 2005 & 2010 & 2011 & 2012 & 2013 & 2014 & 2015 & 2016 \\
\hline $\mathrm{E}$ & 52,22 & 41,83 & 36,19 & 35,23 & 34,27 & 33,21 & 32,39 & 31,51 & 30,61 \\
\hline Bioproduction & 11,761 & 9,421 & 8,150 & 7,934 & 7,718 & 7,479 & 7,295 & 7,096 & 6,894 \\
\hline Years & 2017 & 2018 & 2019 & & & & & & \\
\hline $\mathrm{E}$ & 29,84 & 29,03 & 28,25 & & & & & & \\
\hline Bioproduction & 6,720 & 6,538 & 6,459 & & & & & & \\
\hline
\end{tabular}

Under the environmental code, the geographical monograph of the PNRG reveals 15 protected areas. We decrypt these spaces to calculate the reported footprint respectively. 


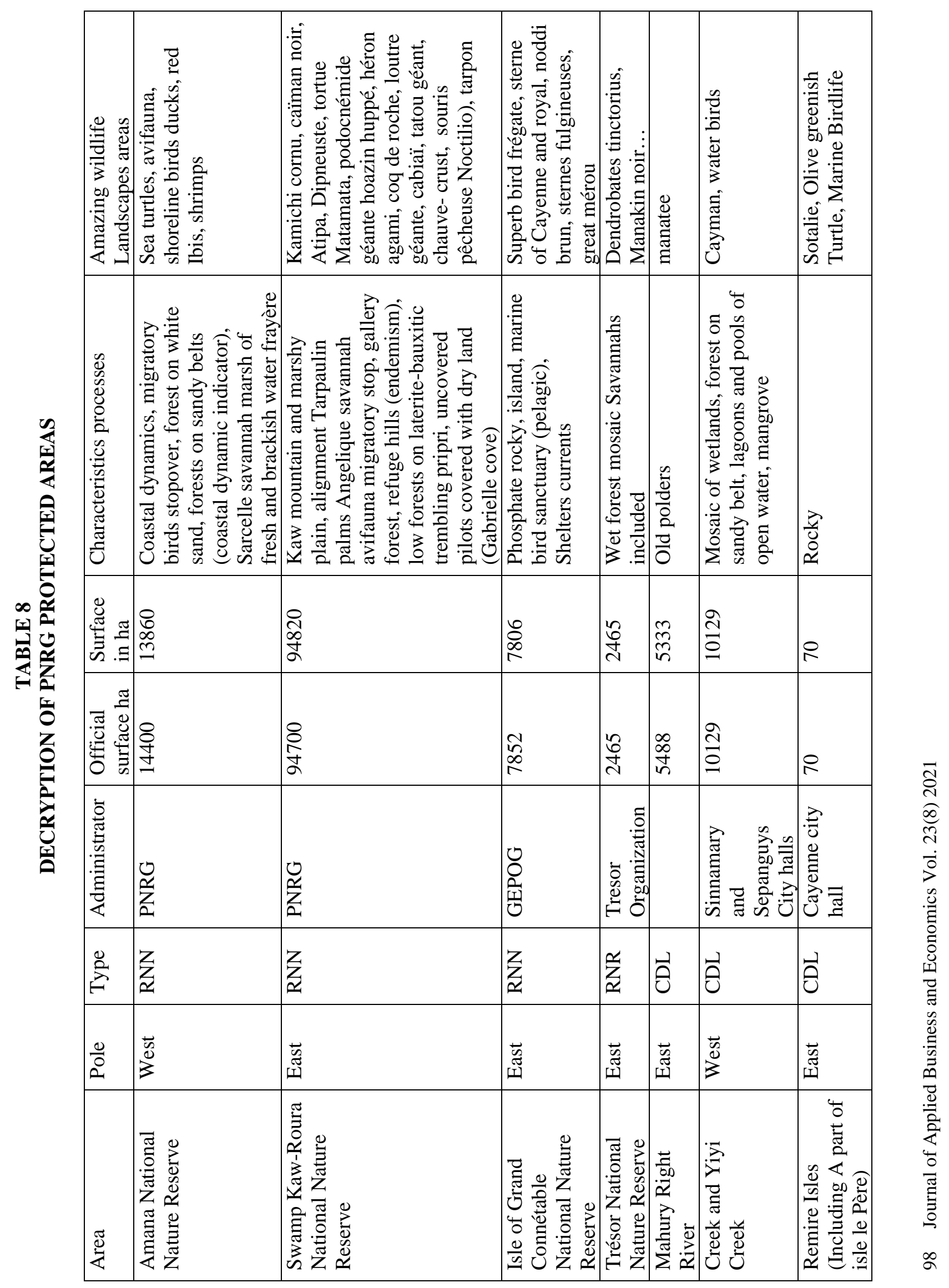




\begin{tabular}{|c|c|c|c|c|c|c|c|}
\hline & & & & 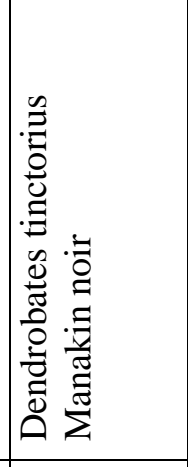 & 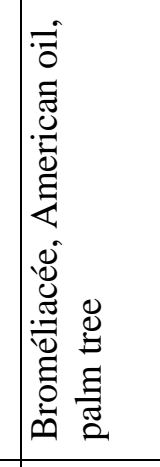 & 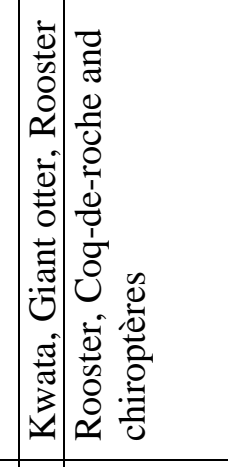 & : \\
\hline & & 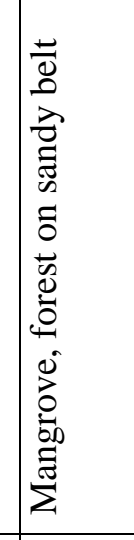 & 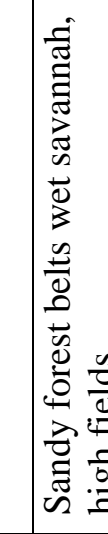 & 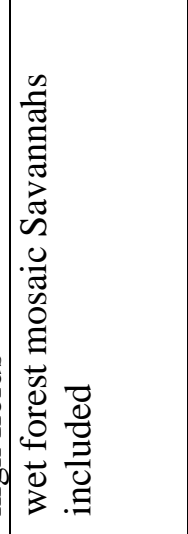 & 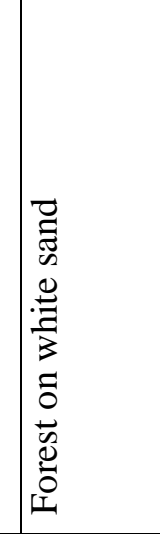 & 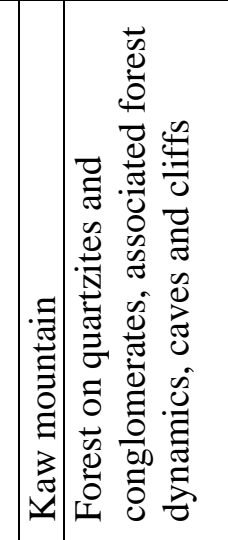 & $\mid$ \\
\hline & $\stackrel{\bar{n}}{ }$ & 8 & $\begin{array}{l}0 \\
0 \\
0 \\
\end{array}$ & 蓉 & \begin{tabular}{|l} 
\\
喜
\end{tabular} & 总 & \\
\hline & $\mid \ddot{b}$ & 8 & 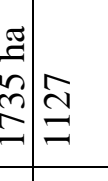 & 尔 & 章 & 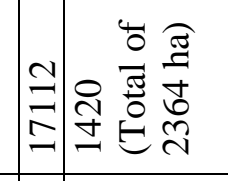 & \\
\hline & 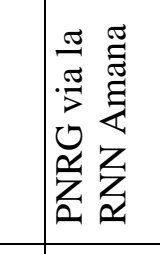 & & & 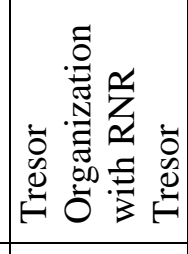 & & 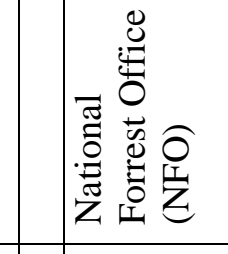 & 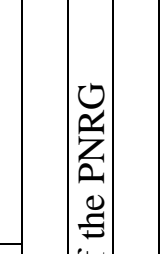 \\
\hline & $\overrightarrow{\hat{\theta}}$ & $\overrightarrow{\hat{\theta}}$ & $\overrightarrow{\mathrm{\theta}}$ & $\vec{\theta}$ & $\frac{\dddot{2}}{2}$ & 爱䊃 & 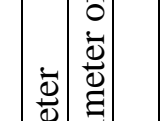 \\
\hline & 落 & 落 & $\overrightarrow{\vec{s}}$ & 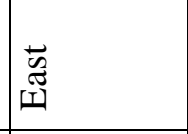 & $\vec{s}$ & 匐总 & \\
\hline & 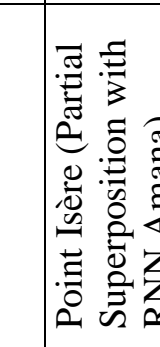 & 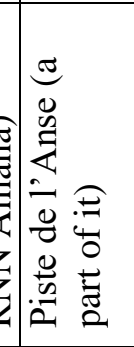 & $\not$ & 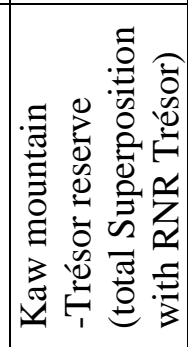 & 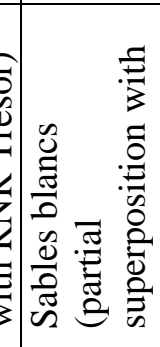 & 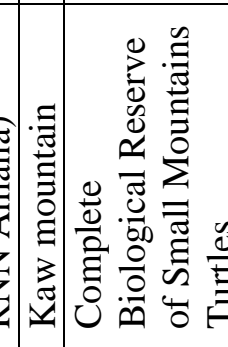 & 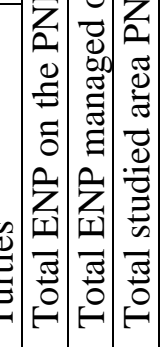 \\
\hline
\end{tabular}




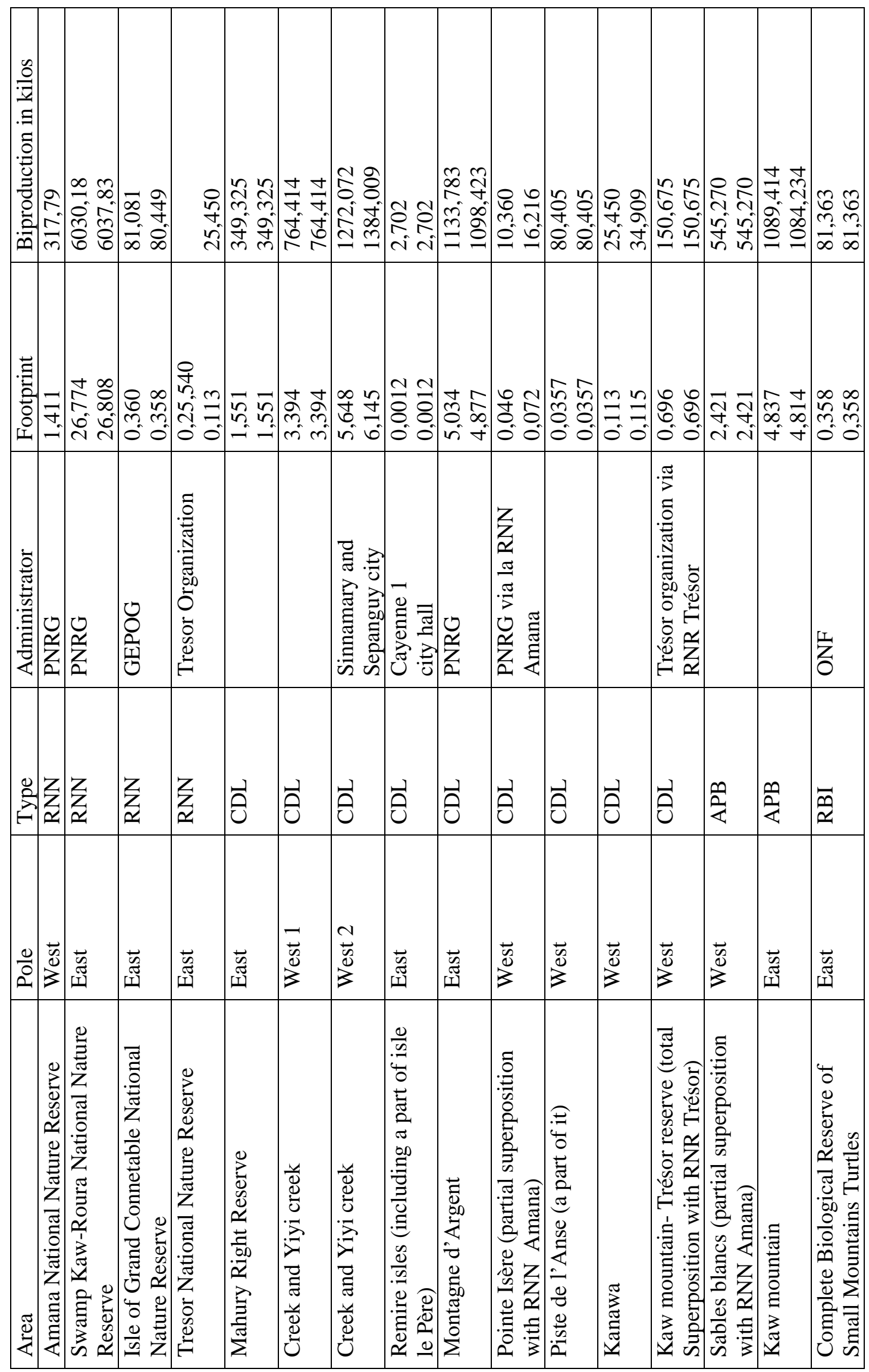

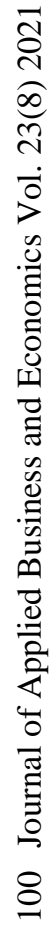


The calculation of the footprint and bioproduction in the case of protected areas in the territory of the PNRG considers the official area and the GIS area in ha. The identification of areas of the municipalities is carried out to connect it to each protected area. The calculation is done by converting the indicator hag to $\mathrm{gm}^{2}$ (global square meters).

\section{Construction of a SWOT Matrix}

To this end, we examine the characteristics of the natural heritage to reveal the strengths, weaknesses, opportunities, and threats (SWOT) relative to the evolution of the footprint and bioproduction. The PNRG area covers a melting pot of environments and species. It is a coastal and coastal wetland with an intense dynamic that allows for the proper functioning of ecosystems. Features are identified. They can be classified in a matrix form.

\section{TABLE 9 \\ THE SWOT MATRIX}

\begin{tabular}{|c|c|}
\hline Strengths & Weaknesses \\
\hline $\begin{array}{ll}- & \text { Ecosystems in good state of conservation } \\
- & \text { Highly patrimonial species } \\
- & \text { Protected areas in various forms } \\
- & \text { Traditional management of environments }\end{array}$ & $\begin{array}{ll}- & \text { Low quantification of threats } \\
- & \text { Poor regulation/enforcement of hunting } \\
- & \text { Poor knowledge of the functioning of } \\
& \text { ecosystems } \\
- & \text { Low protection of certain environments } \\
- & \text { Low valuation of biodiversity } \\
- & \text { No indicator on vulnerability, resilience of } \\
& \text { species and ecosystems } \\
- & \text { Low biodiversity protection }\end{array}$ \\
\hline Opportunities & Threats \\
\hline $\begin{array}{ll}- & \text { High potential for added-value (Education, } \\
& \text { Tourism, Medicinal, artisanal, Agronomic) } \\
\text { - } & \text { Development of new activities } \\
\text { - } & \text { Discovery of new species }\end{array}$ & $\begin{array}{ll}- & \begin{array}{l}\text { Strong pressure on the environment } \\
\text { (urbanization in savannas, agriculture) }\end{array} \\
- & \text { Significant pressure on wetlands } \\
\text { (waterproofing of soil and pollution) } \\
-\quad \text { Uncertainty of the resilience of ecosystems } \\
\text { to climatic and anthropogenic disturbances } \\
-\quad \text { Erosion of the coastline } \\
-\quad \text { Numerous anthropic pressures: poaching } \\
\text { (peak peak bird, entomofauna), hunting / } \\
\text { fishing / harvesting / illegal or abusive } \\
\text { harvesting, poorly respectful practices (urban } \\
\text { planning, incivilities - garbage, agriculture, } \\
\text { weak quantization) } \\
-\quad \text { Pollution of aquatic ecosystems (gold } \\
\text { panning, quarries ...) } \\
\text { Invasive alien plants }\end{array}$ \\
\hline
\end{tabular}

The SWOT analysis highlights issues regarding reconciling human activities with the sensitivity of the environment. It is necessary to preserve resources for sustainable development. However, preservation cannot be applied to an excellent target without a deeper knowledge of the environment. In the management of natural areas, we need to grapple with the issue of ecological continuity and attaining the right balance between protected areas and those dedicated to economic development such as sustainable tourism. 


\section{Forecast and Calculation}

If the footprint is greater than the size of a territory, the survival of the population concerned may be jeopardized in the long term. Fewer natural resources does not mean a reduction in the quality of life, but an ecological debt. Population growth impacts the structuring of the economy and space. As demonstrated previously, the footprint level and bioproduction highlight the risks facing ecology.

On January 1, 2016, 262,527 inhabitants lived in Guiana. The Guianese population was nearly 38,059 more than in 2009 , showing an average annual rate of $+2.4 \%$. Guiana remained the most dynamic French region in terms of population growth, although the pace has slowed down considerably. As there was no net migration, the excess of births over deaths entirely explained the increase in the population. Between 2009 and 2014, population growth was mainly driven by municipalities in the Maroni region. The population of Cayenne decreases by $0.4 \%$ per year and that of Kourou increases slightly by $0.3 \%$ per year.

\section{FIGURE 11 \\ FORECAST FOR THE FRENCH GUIANESE POPULATION IN 2040}

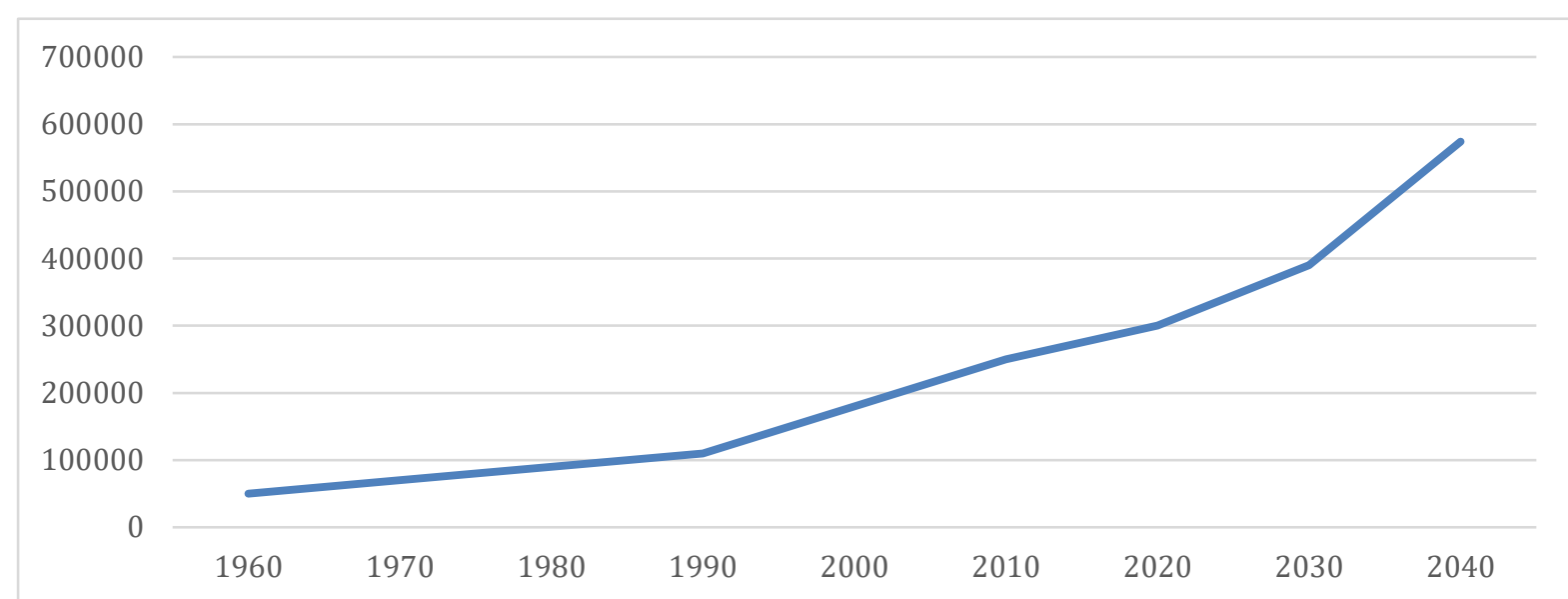

Elaborated by Paul ROSELE CHIM as from National Institute of Statistics and Economics Studies datas French Guyana

The French Guianese population has doubled in 20 years. If the trend continues for the next 20 years, that is, to around 2040, the population will reach 574,000 (National Institute of Statistics and Economics Studies). We can thus calculate the corresponding footprint and bioproduction as shown in Table 10.

TABLE 10

FOOTPRINT AND BIOPRODUCTION

\begin{tabular}{|l|l|l|l|l|}
\hline Years & 2020 & 2025 & 2030 & 2040 \\
\hline E & 27,480 & 24,515 & 22,013 & 14,552 \\
\hline Bioproduction & 6189,189 & 5521,396 & 4957,882 & 3277,477 \\
& 6,189189 & 5,521396 & 4,957882 & 3,277477 \\
\hline
\end{tabular}

\section{CONCLUDING REMARKS}

The studied area presents specificities in terms of social and economic dynamism and the identity of Amazonian territory with a strong potential for biodiversity, cultural heritage, and landscapes. Population growth is a variable for calculating the footprint. $60 \%$ of the Guianese population lives on the PNRG territory (The studied area includes the city and its surrounding municipalities). Rural activities are based 
on the use of natural resources. The latter support the economic activities. They are also closely connected to the cultural heritage.

The West Pole has strong assets to develop cultural tourism, particularly through the history of indigenous populations. The East Pole has assets that are more oriented toward the natural heritage, with large wetlands namely swamps and a typical and migratory wildlife, diverse forest types, rugged fields with savannahs of rocks, peaks, cliffs, and caves. These places are shelter to specific fauna as well as small islands or peninsulas (islands of Rémire, Connétable, Montagne d'Argent).

The studied space has the distinction of being at the interface of land and sea. It comprises diverse environments, and hence, is representative of the Guianese biodiversity with $60 \%$ of noticeable species (migratory species, aquatic birds, bird sanctuaries or savannahs, reptiles, fishes). Natural coastal dynamics maintain the environment and preserve this biodiversity. In some places, the rate of endemism is very high, especially because of the small variations on the paleoclimatic time scale. The outstanding environments, forests on white sand and savannahs, are struggling under high land pressure. The wetlands are exposed to the development of human activities, which have seen an upward trend. Tourism in the wetlands is an illustration.

The population growth of the studied area has a very strong impact on the environment, which has been preserved until now. The results obtained show that the tourist footprint is increasing and the Guianese biocapacity is decreasing. This suggests that in areas where the population is high, the ecological and the tourist footprint increase imply a decline in biocapacity. Geophagy dynamics halted during the 1990s are likely to revive to accommodate the new populations. The challenge for national and local authorities is the anticipation of needs to match natural resource endowments. Much of the needs are derived by exploiting the natural resources (wetlands, lakes, quarries, and sand deposits) in the PNRG territory.

\section{ENDNOTES}

1. Figures from surface treatment by GIS

2. RNN Amana, RNN Marais de Kaw Roura, RNN Connétable, RNR Trésor, Pripri de Yiyi, îlets de Rémire

\section{REFERENCES}

Besse, G., \& Steinfelder, M. (2017). La biodiversité, un des leviers du développement. Report no 01096501, Conseil Général de l'Environnement et du Développement Durable, Ministère de l'Environnement, de l'Energie et de la Mer, May, Paris, France.

Girard, J-L. (2002). l'empreinte écologique: concept et mode de calcul individual. Passerelle Eco, 10, 1019.

JIE. (2016). Ecological footprint analysis applied to mobile phones. Journal of Industrial Ecology, 10(12), 216-299.

Lamiot, F. (2003). L'empreinte écologique des villes. Revue Etudes Foncières, 102, 8-15.

Rees, W., \& Wackernagel, M. (1999). Our ecological footprint. Vancouver, Canada: Ecosociety Publishers.

Rieucau, J., \& Lageste, J. (2017). L'empreinte du tourisme: Contribution à l'identité du fait touristique. Paris, France: Edition L'Harmattan.

Rosele Chim, P. (2014). Les défis du développement du tourisme et l'intelligence économique des territoires: Ville sur mer et en terre. Paris, France: Edition Publibook Université.

Rosele Chim, P. (2018). Analysis of creative tourism by providing emotion, participation and sociality through film and carnival. AIMTD Academic Conference, 9th JSTD, California State University East Bay, San Francisco, April, USA.

SAR. (2016). Schéma d'Aménagement Régional de la Guyane. D ROM - COM, July 6, Cayenne, Guyana. 
Seraphin, H., Rosele Chim, P., Gowreesunkar, V., Korstanje, M., \& Duplan, Y. (2018). Tourism planning and innovation: The Caribbean under the spotlight. Journal of Destination Marketing and Management. Elsevier B.V Radarweg 29, 10NX Amsterdam.

WWF, GFN, ZSL. (2008). Living Planet Report. WWF, Global Footprint Network and ZSL Living Conservation.

\section{APPENDIX}

\section{FIGURE 12 \\ TOURISM PRACTICE IN FRENCH GUIANA IN MANGROVE}

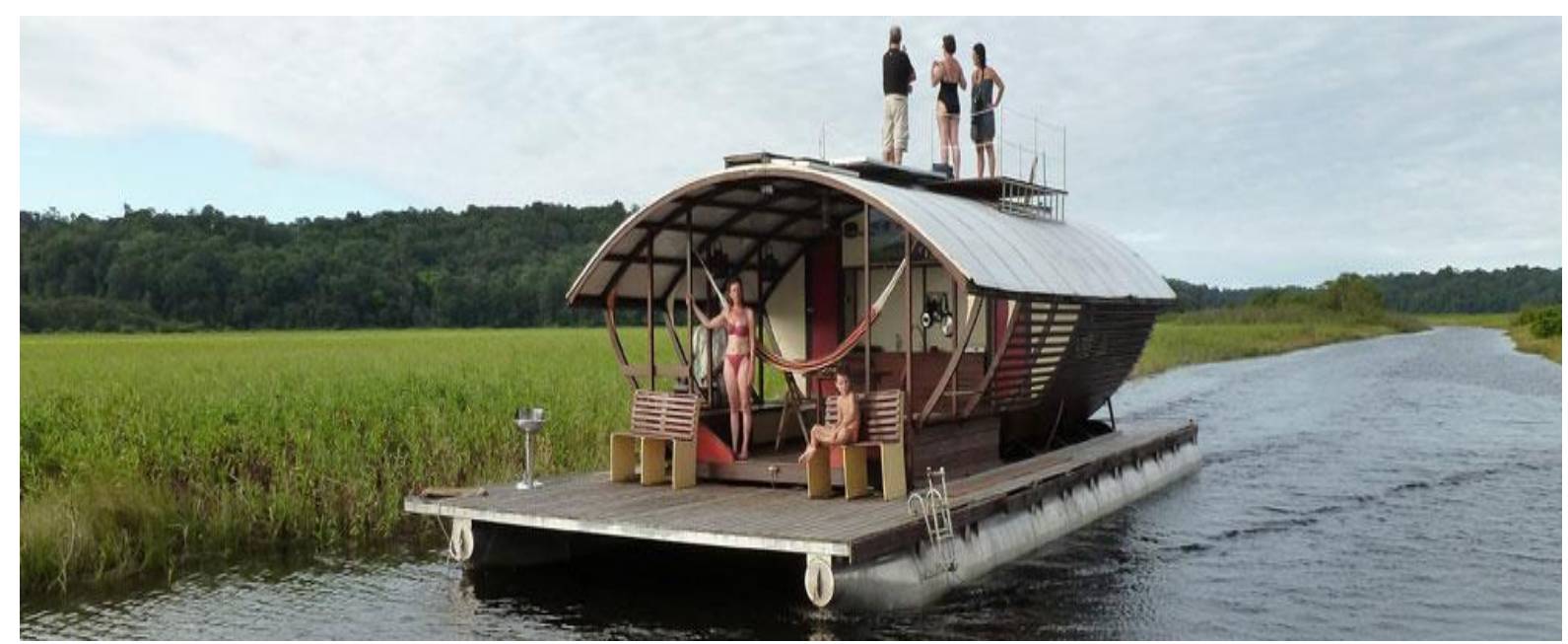

Photo: JAL Voyages

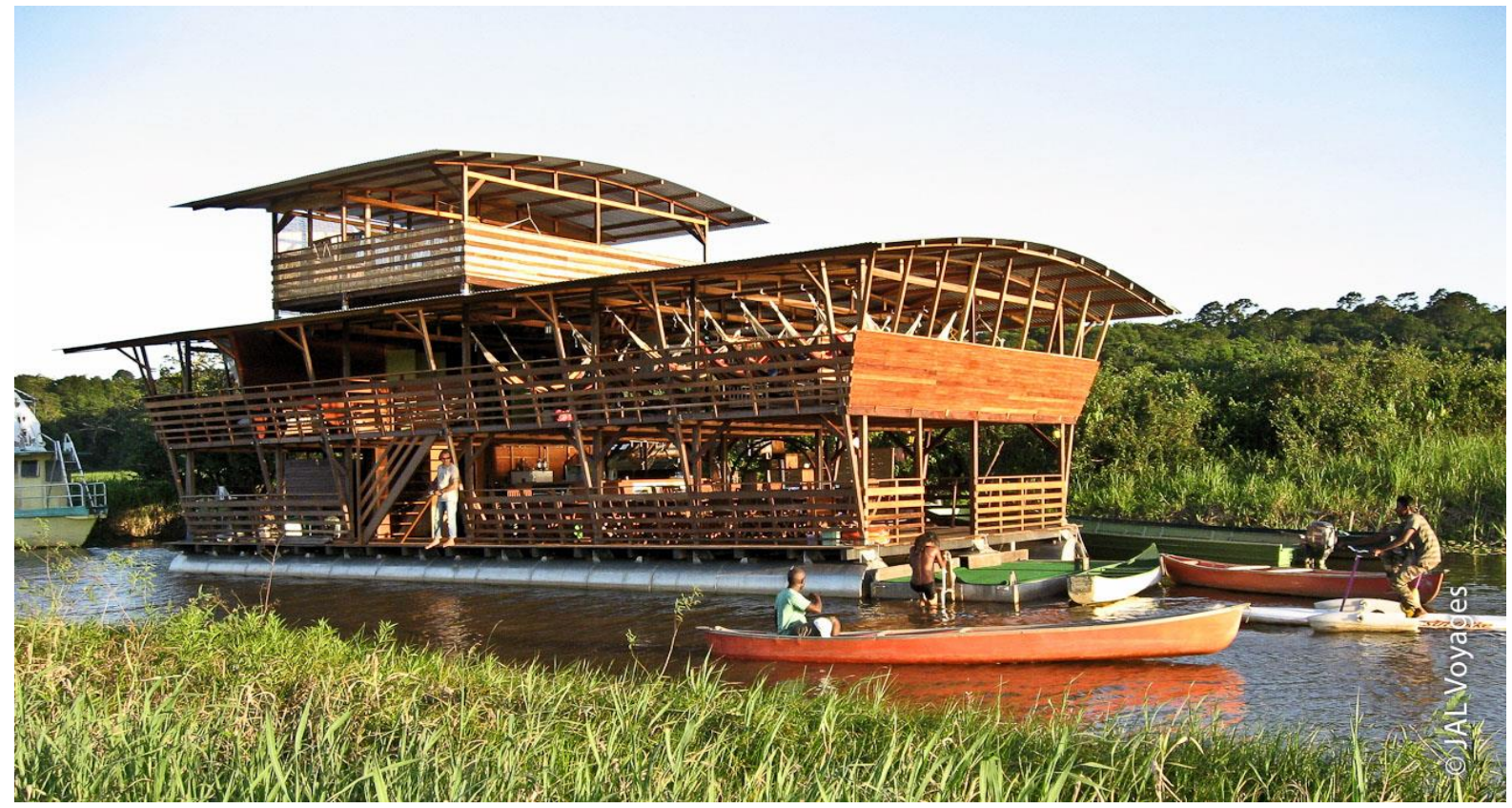

Photo: JAL Voyages 